\title{
The status of immigrants on Italian labour market in the context of economic decline: Evidence from survey, macroeconomic and big data
}

\section{Mihaela Simionescu}

\author{
Institute for Economic Forecasting of the Romanian Academy, Bucharest, Romania
}

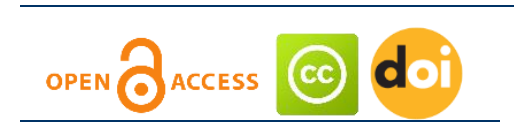

Article history:

Received: March 09, 2021

1st Revision: March 14,

2021

Accepted: April 09, 2021

\section{JEL classification: \\ B23 \\ $\mathrm{J} 61$ \\ J64 \\ J81}

\section{DOI:}

10.14254/jems.2021.6-1.3

\begin{abstract}
Considering the impact of economic crisis on Italian labour market, the aim of this paper is to analyse the status of immigrants from Italy in the labour field using more sources of data: survey data from the research "Case study of Labour Force Survey", macroeconomic data from official statistics of Eurostat and big data associated to Internet queries on Google. Survey analysis for the 20 regions in Italy confirmed the foreign women advantage of finding a job better than foreign men. The decline in the GDP at regional level affected the immigrants, but their searches for jobs on the Internet were significant in explaining the status of immigrants on labour market. The data at national level used in estimating Bayesian generalized ridge regression suggested that the number of unemployed immigrants from Italy since 2008 is explained by changes in risk of poverty or social exclusion, exports of goods and services, housing cost overburden rate, inflation and tax rate on low wage earners and adult participation in learning.
\end{abstract}

Keywords: immigrants, economic crisis, labour market, big data.

\section{Introduction}

The global economic recession started in 2007-2008 affected Italy since 2009, when GDP felt and unemployment quickly grew. The government instability contributed to public debt growth and to downgraded credit rating of Italy in 2011. In this year, the number of Italian immigrants decreased, unemployment becoming an acute issue. However, most of the immigrants continued to stay in Italy for fear of economic decline in their origin countries and made efforts to adapt to worse conditions of work.

Italy kept the highest public debt in Europe, being officially in the present the single EU country in recession. This difficult economic situation has consequences on the immigrants' status on Italian labour market. Previous studies indicated that in period of economic recessions changes in the migrants inflows and more returns home were observed (Trenz \& Triandafyllidou, 2017). On the other hand, Papademetriou et al. (2010) showed that the migrants' decision to return home is 
more influenced by economic conditions in the origin countries rather than economic recession in the host countries. In case of restrictions of migration flows in economies affected by economic crisis, the channel of entrance for migrants might change (Hatton and Williamson, 2009). The structure of the foreign labour supply changed during the recent economic crisis because of the reduction in the labour channel of entrance and growth in the family reunification channel.

Italy has a segmented labour market, the foreign workers being mostly concentrated in lowpaid and low-skilled jobs, even if some of them are highly educated. Unlike the migration situation in other EU countries, Italy did not diminish the overall immigrants flows during the years of economic crisis. The foreign employment was lower since 2008 compared to previous years, but it continued to maintain at high level after 2008 even when GDP dramatically fell. From this point of view, Italy is an exception among Southern European countries that registered very high decrease of foreign employment in the recent economic recession (Venturini \& Villosio, 2018). Therefore, we selected Italy in the analysis since it presents specific characteristics that are different from the global trend in migration.

In this context, an analysis of the immigrants from Italy since the global crisis start is made using data from different levels: microeconomic data from surveys, macroeconomic data from official statistics and big data collected using Google Trends tool. The results based on these three approaches using binary logistic regressions and generalized linear models, Bayesian ridge regressions and, respectively panel data models conduct us to the same conclusions. The insertion of immigrants on the Italian labour market during the economic crisis depends on demographic characteristics, economic conditions in the destination country and searches for jobs on the Internet.

Firstly, the paper focuses on the presentation of status of foreign people on the Italian labour market from previous studies in the literature. The next section describes data and methodology that will be used to get empirical results for situation of foreign people on the Italian labour market since 2008. In the end, few conclusions are drawn.

\section{Literature review}

Most of the Italian immigrants established in this country for work purposes. The largest community of immigrants in Italy is represented by the Romanian community (more than 1.2 million Romanian immigrants in 2019, according to latest official statistics). Other large communities of Italian immigrants come from countries like Albania, Morocco, Ukraine, Republic of Moldova, China, Philippines, India and Bangladesh. These immigrants integrated on the Italian labour market, covering the labour deficit in those sectors requiring unskilled work. Even if immigrants in Italy are met in sectors with considerable physical labour load, their salaries are low and the work conditions are poor. Because of demographic ageing that deeply affected the Italian society and the tendency of women to continue working, the family sector that requires assistance for the elderly is dominated by immigrants (Del Boca \& Venturini, 2016). Males from foreign countries work in Italy in sectors like: construction, agriculture, industry and commerce. Most of the females are met in family services sector. Around $15 \%$ of women work in services sector, especially commerce and only a low percent in industry. Cheap and unqualified labour force provided by immigrants in care sector determined changes in migration policies in Italy. After the recession in 1971, Italy became a country of immigration. The restrictive immigration policies promoted by Northern countries, Italy began to transform in a destination countries for many migrants. After the first EU enlargement in 2004, Italy requested a period of transition of 3 years for immigrants, but after the second enlargement in 2007, this transition period was not required any more.

Studies related to the status of immigrants on Italian labour market appeared many years back. Based on a regional and sectorial approach, Gavosto et al. (1999) showed that the employed immigrants had a positive contribution on natives' wages in the period 1989-1995. A different result was obtained by Romiti (2011) for employees in the private sector in the period 1987-2004. The author showed that low-skilled immigrants reduced the salaries of higher-skilled immigrants and the wages of natives, but to a lower extend. A "glass-ceiling" effect was observed in the case of immigrant workers, which supposes strong barriers for Italian migrants to access high paid jobs (Carlo et al., 2012).

Venturini and Villosio (2006) showed that job search effectiveness reduced in the case of young natives without experience in the presence of foreign workers only in 1993. In the case of Italian natives, the probability of transition from unemployment to employment is not influence by immigrants. A deeper analysis was made by Venturini and Villosio (2008) later who observed significant differences between Italians and immigrants in what concerns unemployment. The highest differences in employment and wages were observed in construction sector, while in services and manufacturing the differences are lower. Fewer perspectives in work for foreign workers forced them to have temporary jobs and to alternate legal employment with illegal one. On the other hand, 
Romiti (2011) analyzed data from private sector and concluded that there is a small and imperfect substitution between natives and immigrants. Barone and Mocetti (2010) found that the employment of foreign women in Italy does not affect the labour force participation of native women. Moreover, Romiti and Rossi (2011) showed that the decision of native females to leave earlier the labour market by at least one year is influenced by immigrants, a large part of them being employed in family services. Ambrosini (2013) showed that Italian government supported migrants to work in the care sector, especially for elder people to cover the shortage in this field. Italian elderly benefit from public pension, but they also receive an attendance allowance to pay the services of care offered by immigrants.

The consequences of economic crisis on migrants might be alleviated by the free mobility regime in case of EU citizens that eliminates the restrictions on returning to the origin country (Kahanec et al., 2009). In the context of economic recession, there are high chances to give up to migration projects, increasing the cost of migration, especially for migrants belonging to countries far away from host countries. Therefore, migrants coming from Eastern European countries continue to establish in Italy and other EU countries despite economic prospects. According to recent surveys, the economic recession made Italian immigrants less eager to come back to their origin countries (Hinks \& Davies, 2015).

The channel of entrance has been modified during the crisis years. Starting with 2011, a decrease in the number of migrants due to work purposes was observed while he migrants that come for family reunification registered certain stability. The new flows of immigrants tend to work in the same sector as their relatives that are already established there.

Only few studies focused on the status of Italian immigrants in the context of recent economic crisis. For example, Venturini and Villosio (2018) showed that immigrants were partially protected from the negative effects of world economic crisis, but the segregation in what concerns unstable, low-skilled and poorly paid jobs increased. The typical jobs for these immigrants are known in literature as 3-D jobs: dirty, difficult and dangerous. This term refers to less protected, less paid and less stable jobs (Arango et al., 2009).

Italian economy still offered jobs for immigrants during the economic crisis due to foreign people adaptability to poor working conditions and low-skilled jobs. Before great recession, Italian labour market was characterized by two levels of segmentations: foreign men worked in construction and manufacturing sector, while foreign women preferred to work in manufacturing, household services, restaurants and hotels. This polarization explained by Zanfrini (2015) for migrants concentrated in "ethnicized" jobs is has changed in crisis times. Even during economic recession, foreign employment in Italy continues to maintain a positive trend. More studies showed that the Italian immigrants' participation rate on labour market during the economic recession is better than participation of nationals (Carvalho, 2013; Ambrosini, 2013; Hollifield et al., 2014; Zaiceva \& Zimmermann, 2016; Del Boca \& Venturini, 2018).

However, the economic recession has negatively influenced the inflows of foreign men that were more affected than native males. The unemployment rate dramatically grew in case of foreign males compared to natives. The increase of unemployment rate for foreign females is lower compared to males. The capacity of labour market to retain Italian immigrants that seek for a job reduced because of the economic crisis. The incidence of foreign males in typical migrant occupations kept during the crisis while their concentration reduced. The polarization in these jobs for foreign females increased.

The actual economic context in Italy marked by the recent world economic crisis caused unemployment not only among nationals, but also among immigrants. For the first time since 2008, a decrease in the number of immigrants coming from Romania, Albania, Morocco, Egypt and Sri Lanka was observed in 2011 because of the economic recession. After this year, the number of Romanian immigrants continued to increase while the number of Albanians, Moldavians and Moroccans registered a descending trend in the period 2015-2019.

The status of immigrants on Italian labour market is connected to demographic structure and living conditions. In Italy, the economic decline changed the demographic structure of the immigrants and worsened their living conditions. Demographic characteristics like gender are important, since gender distribution in specific sectors of activity conditions exposure to unemployment (Otobe, 2017). Ethnicity, country of origin and race condition the likelihood of unemployment (Albu et al., 2010; Fleischmann \& Dronkers, 2010).

The migratory policies do not focus on strategies that may help migrants to face the unemployment generated by economic crisis. Sacchetto and Vianello (2016) observed coping strategies applied for facing the unemployment among Romanian and Moroccan migrants from Italy. The results based on survey data suggested that Romanian people have more chances to find a new job in Italy during the crisis compared to Moroccans, because they are more stable and integrated in social networks and less discriminated. Tilly (2011) suggested the intensification of immigrants 
discrimination during the crisis associated to worse conditions of living and working. Immigrants tend to accept bad paid jobs in worse conditions of working, because they could not remain for a long time in unemployment (Reyneri \& Fullin, 2011). There are more reasons that explain the life quality worsen of Italian immigrants during the economic recession. In general, foreign works have fewer rights than the nationals and benefit from less welfare protection, being more exposed to social risks (Calavita, 2005; Schmiz, 2013). Immigrants tend to have temporary jobs and low-skilled jobs in the most exposed sectors to economic crisis (construction and services) as Awad (2009) and Papademetriou et al. (2010) showed.

The measures for reducing unemployment in Italy should be related to the control of public debt and a better labour market regulation. The labour reform made in 2012 increased labour market flexibility, but the protection of employees from unfair dismissals is still an important issue.

\section{Data and methods}

In this empirical research, the status of Italian immigrants since 2008, when the global financial crisis started, is analyzed using microeconomic, macroeconomic and big data. The source of microeconomic data is represented by Eurostat survey for the research "Case study of Labour Force Survey" (LFS) for each year in the period 2006-2018. This database is offered by the National Institute for Statistics in Italy (Istat).

Some questions in the questionnaires designed for this survey are related to demographic characteristics of Italian immigrants like gender, age, level of education, region of residence in Italy, family typology and marital status. Other questions refer to immigrants' status of labour market: professional position in the main and second activity, the period of absence from work and the period of being not occupied, the period of unemployment or of searching for a job. The absence from work caused by unemployment is constructed as an alternative variable with the two possible values "Yes" and "No". The professional position in the main or second activity might take one of the following values: employee, collaborator and independent. Other questions are related to: wave of immigration, place of birth, type of employment contract, residence country one year before, sector of activity, seniority, and net income.

Based on these data, we computed a new variable called "perceived as employed/unemployed" to identify the status of each immigrant. Each analyzed sample is representative for the population of Italian immigrants. The number of questioned immigrants varies each year.

Beside these microeconomic data, we explained the number of unemployed immigrants from Italy using as explanatory variables some indicators at national level. The number of unemployed immigrants was computed based on data in the sample and applying some weights to get the number of population.

We denoted by $\mathrm{p}$ the probability of an individual to be employed. The odds ratio (OR) or likelihood ratio is associated to the event of being employed or unemployed.

$$
O R=\frac{p}{1-p}
$$

The logarithm of odds ratio is determined as:

$$
\ln \frac{p}{1-p}=b_{0}+b_{1} X+\varepsilon
$$

where:

$\mathrm{X}$ - explanatory variables;

$b_{0}, b_{1}$ - coefficients;

$\varepsilon$ - error.

If $\mathrm{OR}=1$, then at each increase in the explanatory variable by one unit, the odds remain the same (that explanatory variable has no significant impact on the status of Italian immigrants on labour market).

If $O R>1$, then at each increase in the exogenous variable by one unit, the probability to be unemployed grows by $e^{\widehat{b_{1}}}$ times.

If $0 R<1$, then at each increase in the exogenous variable by one unit, the probability to be unemployed decreases by $e^{\widehat{b_{1}}}$ times.

We are also interested in explaining the duration of searching for a job and the duration of being not occupied. These variables are explained using generalized linear regression models (GLM). This type on model generalizes the ordinary linear regression under the hypothesis that endogenous variable has errors with a different distribution than the normal one. The linear model is connected 
to response variable through a link function. In the case of each measurement, the variance's magnitude is expressed as a function of the corresponding predicted value. More variables act like explanatory variables in the models: gender, level of education, dependence (dependent, independent as professional condition), marital status, net monthly income.

The data for explanatory variables were provided by Eurostat: GDP in PPS, exports, housing cost overburden rate, people at risk of poverty or social exclusion, employment in knowledgeintensive activities, harmonized index of consumer prices, impact of social transfers (excluding pensions) on poverty reduction, adult participation in learning, tax rate on low wage earners, labour productivity per person employed and hour worked. The variables were selected according to economic theory:

- GDP is inversely correlated to unemployment according to Okun law, this correlation being previously checked in the context of recent economic crisis for developed and developing countries by Bartolucci et al. (2018) ;

- $\quad$ Exports could be correlated to unemployment since the intensification of exports creates jobs opportunities that reduce unemployment (Subramaniam, 2008);

- Inflation and unemployment are correlated according to Phillips curve, but this relationship should be checked using empirical data (Simionescu, 2014);

- Housing costs and poverty might growth during the financial crisis might influence the labour market in both directions as Saunders et al. (2016) showed for the recent economic crisis;

- $\quad$ Aspects related to labour market are connected to unemployment issue (social transfers, labour productivity, tax on low wage, employment in knowledge-intensive activities) (Barnichon, 2010);

- Adult participation in learning is related to unemployment since a part of unemployed people are subject to different learning programs to improve their (re)insertion of labour market (Pont, 2004).

The adult participation in learning is computed as a ratio of two components: the share of people aged 25 to 64 years receiving education (formal or non-formal one) and training in the last four weeks before survey and the population in the same group of age.

Housing cost overburden rate expresses the proportion of population living in a household for which overall housing costs exceed $40 \%$ of the total disposable income of that household.

Impact of social transfer on poverty reflects the diminution of the risk of poverty rate, due to contribution of social transfers.

The maximum number of unemployed immigrants in Italy in this period (2008-2018) was achieved in 2013. Indeed, in 2013 Italy reached the highest level of unemployment since 1977, the maximum value being registered in May 2013 (12.2\%). Moreover, youth unemployment was 40\% in 2013, too higher compared to the average level of EU that was 23.5\%. Unemployment has not recovered from crisis, this social issue affecting not only nationals, but also immigrants.

A Bayesian generalized ridge regression was built to select which of these variables explain the number of unemployment immigrants on Italian labour market since the start of the recent global economic crisis.

We assume $\beta$ as standardized coefficients (posterior means) based on centred mean and normalized explanatory variables of null average and variance equalling 1 (Karabatsos, 2014). If the exogenous variables are not correlated, the coefficients lie between -1 and 1 .

We considered the posterior probability that the standardized coefficient is within 1 standard deviation of 0 (PP1SD). There is a significant influence of an explanatory variable on dependent variable if PP1SD is lower than 0.5.

Let us consider $\mathrm{b}$ as unstandardized parameters on the original scale of the variables. These coefficients are computed using the values of beta.

$$
b=\left[\bar{y}-\frac{\bar{X} \cdot \beta}{\mathrm{SD}(\mathrm{X})^{\prime}}, \frac{\beta}{S D(X)}\right]
$$

$\bar{y}$ represents the average of the values corresponding to dependent variable.

The first value of $\mathrm{b}$ is represented by the intercept, while the rest of the values are slopes. The means of the explanatory variables are included in a row vector $(\bar{X})$. Standard deviations of the exogenous variables are included in a column vector $\left(\operatorname{SD}(\mathrm{X}){ }^{\prime}\right)$. 
Beside these approaches based on microeconomic and macroeconomic data, we consider panel data models that include big data corresponding to searches on Google for some key-words: subito it lavoro and offerte di lavoro. These key-words were previously used in few studies to explain unemployment rate in Italy (Francesco, 2009; D'Amuri \& Marcucci, 2010; Falorsi et al., 2017; Naccarato et al., 2018).

The following fixed effects regression models were constructed: number of unemployed immigrants

$$
=\beta_{1} \cdot \text { offertte di lavoro }_{i t}+\beta_{2} \cdot \Delta G D P_{i t}+\beta_{3} \cdot \text { subito it lavoro }_{i t}+\alpha_{i}+u_{1 i t}
$$

number of employed immigrants it $_{i t}=\gamma_{1} \cdot$ offertte di lavoro $o_{i t}+\gamma_{2} \cdot \Delta G D P_{i t}++\delta_{i}+u_{2 i t}$

where

$\mathrm{i}=1, \ldots, \mathrm{n}$ and $\mathrm{t}=1, \ldots, \mathrm{T}$.

$\beta_{1}, \beta_{2}, \beta_{3}, \gamma_{1}, \gamma_{2}$ - coefficients

$u_{1 i t}, u_{1 i t}$ - error terms

$\alpha_{i}$ and $\delta_{i}$ represents entity-specific intercepts capturing those heterogeneities observed across regions.

After the construction of panel regression models, regression assumptions will be checked. Heteroscedasticity of errors will be analysed using the likelihood ratio tests. We will also check if the error terms are not correlated.

\section{Results}

The status of Italian immigrants (employed/unemployed) according to their response in the Eurostat survey is explained based on demographic and economic variables as we can observe in Table 1 . The p-values are zero in all cases, which was expected since the data base is very large.

\begin{tabular}{|c|c|c|c|c|c|c|c|c|c|c|c|c|c|}
\hline Variables & 2006 & 2007 & 2008 & 2009 & 2010 & 2011 & 2012 & 2013 & 2014 & 2015 & 2016 & 2017 & 2018 \\
\hline Gender & 1.947 & 1.977 & 1.895 & 1.551 & 1.492 & 1.678 & 1.413 & 1.228 & 1.265 & 1.313 & 1.471 & 1.504 & 1.636 \\
\hline $\begin{array}{l}\text { Lived } \\
\text { always in } \\
\text { Italy } \\
\text { (available } \\
\text { since 2008) }\end{array}$ & - & - & - & 1.046 & - & 0.969 & 0.997 & 1.691 & 1.228 & 1.426 & 1.458 & 1.310 & 1.238 \\
\hline $\begin{array}{l}\text { Education } \\
\text { level (less } \\
\text { than high } \\
\text { school, high } \\
\text { school, } \\
\text { more than } \\
\text { high } \\
\text { school) }\end{array}$ & 0.726 & 0.609 & 0.731 & 0.885 & 0.692 & 0.862 & 0.903 & 0.857 & 0.842 & 0.878 & 0.849 & 0.801 & 0.836 \\
\hline $\begin{array}{l}\text { Age classes } \\
(20-64 \\
\text { years old })\end{array}$ & 0.79 & 0.768 & - & - & 0.736 & 0.868 & 0.855 & 0.857 & 0.857 & 0.837 & 0.891 & 0.903 & 0.856 \\
\hline $\begin{array}{l}\text { Country of } \\
\text { citizenship }\end{array}$ & 1.111 & - & 1.192 & 1.051 & 1.129 & 1.040 & 1.010 & 1.040 & 1.046 & 1.036 & 1.018 & 0.970 & 1.010 \\
\hline Constant & 0.055 & 0.087 & 0.011 & 0.071 & 0.166 & 0.146 & 0.235 & 0.205 & 0.252 & 0.235 & 0.128 & 0.198 & 0.144 \\
\hline
\end{tabular}

Source: own calculations

According to binary logistic regression models, the females have more chances than males to be employed on Italian labour market. The result is consistent with expectations and with previous studies that explain the structure of the Italian labour market in terms of immigrants. Italy needs foreign workers in those sectors that are dominated by women (jobs in restaurants and hotels, elderly care, health sector, domestic work) (Stan, 2005). The economic crisis in Italy affected agriculture and construction sector which brought a decrease in the number of males. Other studies considered that men preferred to come back in their origin countries to start-up businesses with the people from Italy, while women integrated well in the Italian families and were less eager to come back in their origin countries (Vlase, 2013). The gender distribution could be also explained by the migration reasons that are different for each gender. Females are interested in family reunion and career opportunities, while men just look for a job in order to improve the economic condition (Mara, 2012; Cohen, 2017). 
The odds ratio indicated lower chances for Italian immigrants to remain in this country in 2011 and 2012, in these years of recessions. The result is confirmed by the tendency of circular migration that characterized the recent world economic crisis.

Immigrants with more than high school have less chances to get employed compared to those than have high school or less. In 2007 and in 2010, before crisis start and in the recession year, immigrants with higher education have fewer chances to get employed on Italian labour market. The results are in line with expectations and with previous studies that show the preference of immigrants with higher studies to make a slave labour (Reyneri, 2006; Minneci, 2015) as long as they gain money from this. In general, the unemployment rate for Italian immigrants are rather low, because they accept those jobs that require few qualifications and are not usually preferred by natives (Reyneri and Fullin, 2011). At national level, in Italy, the level of education is positively associated with the employment (Fullin and Reyneri, 2011). By contrast, this relationship is not significant for immigrants. Higher education does not offer any protection to Italian immigrants against the risk of unemployment. The skills acquired by these immigrants in the educational system of the origin country are considered useless, because human capital is country-specific (Heath and $\mathrm{Yu}, 2005)$. It is specific for Italy to not recognize the qualifications obtained in another country. Recent immigrants came in Italy for work and do not have enough economic and social resources to afford waiting too much for getting a job. In this context, they are forced to accept a job that does not required higher qualification and under poor working conditions. Therefore, in Italy the employment opportunities for immigrants are focused on unskilled positions.

Passing from one class age to another, the chances for immigrants to be employed decrease. The lowest chances to get employed when their age increased were registered in 2010, in the year of recession. Most of the Italian immigrants are young people, with higher physical capacity of work that could afford to make the unskilled jobs with hard physical work while older people have less capacity to accomplish these jobs duties (Schreiner, 2008; Uccellini, 2010). Age class was not a significant predictor in 2008 and 2009, on the economic crisis start, since all the categories of age were affected by the new economic changes.

Romanian immigrants have higher chances to be employed compared to immigrants from other countries, because they are the largest community in Italy and most of them are interconnected in a network that help them to find easier a job. Only in 2017, Romanians have lower chances to have a job in Italy.

The duration of search for employment in the case of Italian immigrants is explained using Eurostat data and a generalized linear model for the period 2008-2018.

\begin{tabular}{|c|c|c|c|c|}
\hline Parameter & $\mathrm{B}$ & Std. Error & $\mathrm{T}$ & Sig. \\
\hline Intercept & 75.717 & 0.238 & 318.338 & 0.000 \\
\hline Region & 2.501 & 0.007 & 364.254 & 0.000 \\
\hline Gender & -6.266 & 0.083 & -75.863 & 0.000 \\
\hline Level of education & -2.657 & 0.056 & -47.496 & 0.000 \\
\hline Dependence & 0.865 & 0.060 & 14.392 & 0.000 \\
\hline Marital status & -5.649 & 0.047 & -120.136 & 0.000 \\
\hline Net monthly income & 0.191 & 0.001 & 202.423 & 0.000 \\
\hline
\end{tabular}

Source: own calculations

The duration of search for employment is positively correlated to net monthly income. Immigrants from households with higher income prefer to wait more till they find a better paid job.

Females need less time to find a job compared to men, fact that is confirmed by expectations and by previous studies (Stan, 2005; Simionescu, 2017). This result is also confirmed by the binary logistic regression. Women find easier jobs in care and health sector, restaurants and hotels, domestic work, agriculture while men work mostly in construction and agriculture that in economic crisis were deeply affected. A recessional dynamics was observed in building sector in Italy up to 2013. The recovery sign were observed since 2014, but they were slow and a lot of immigrants in this sector were forced to come back to their origin countries or to be unemployed (Ruggiero, 2018).

People with higher level of education wait less till they find a job since they have more skills that could allow them to make more types of unqualified jobs. Moreover, immigrants came in Italy for money and higher educated ones are aware that they could not find a job according to their skills and prefer to make any unskilled job as long as they receive a salary (Fellini, 2018).

A dependent person spends less time to get a job, compared to an independent one. Probably, a dependence person does not want to be a burden for the rest of the family. A married person finds easier a job, because that individual is forced to get a job faster to support the family, while a single 
person prefer to wait more till find a better job since his/her expenses are less than those of a household with children. Moreover, Bonifazi and Paparusso (2019) showed that married migrants have the lowest chances to return in their origin countries, making efforts to keep a job in Italy or to find quickly another one in case of unemployment.

The duration of being not occupied for Italian immigrants is explained using a generalized linear model (Table 3).

$\begin{aligned} & \text { Table 3: Generalized linear model to explain the duration of being not occupied (in months) } \\
& \text { for Italian immigrants (2008-2018) }\end{aligned}$
\begin{tabular}{lcccc}
\hline Parameter & $\mathrm{B}$ & Std. Error & $\mathrm{t}$ & Sig. \\
\hline Intercept & -2.400 & 0.037 & -64.610 & 0.000 \\
Region & 0.002 & 0.001 & 2.337 & 0.019 \\
Gender & 1.650 & 0.011 & 146.822 & 0.000 \\
Level of education & -0.907 & 0.008 & -112.739 & 0.000 \\
Dependence & 2.909 & 0.008 & 353.997 & 0.000 \\
Marital status & 0.273 & 0.006 & 44.053 & 0.000 \\
Net monthly income & 0.007 & 0.000 & 49.667 & 0.000 \\
\hline
\end{tabular}

Source: own calculations

People with higher education are more occupied than those with lower education since they are more motivated to work and have enough skills that allow them to be implied in an activity. In general, males are more occupied than females, the latter changing faster a job because they find easier a new job that is better paid and provides better working conditions. Moreover, the weaker labour participation of females in Italy is explained by the lack of a strong formal childcare which forces women to stay home with children. Independent immigrants are less occupied than dependent ones since they have autonomy in organizing their activities. For people with higher net income the duration of being not occupied is longer since they prefer to wait for a better paid job. Married people have a shorter period of being not occupied compared to single ones since they have more duties that require salary.

Beside this microeconomic approach based on representative samples of immigrants for Italian population, we analyzed the status of these immigrants on labour market using a macroeconomic approach. A generalized ridge regression model in a Bayesian framework of estimation was built to explain the number of Italian immigrants in the period 2008-2018 (Table 4).

\begin{tabular}{|c|c|c|}
\hline Covariate & $\begin{array}{l}\text { Standardized Coefficients } \\
\text { (posterior mean) }\end{array}$ & $\begin{array}{c}\text { Posterior probability that the } \\
\text { standardized coefficient is within } \\
1 \text { standard deviation of } 0\end{array}$ \\
\hline GDP & -620498.993 & 0.572 \\
\hline Exports & 3281704.595 & 0.303 \\
\hline Housing cost overburden rate & 891536.616 & 0.177 \\
\hline $\begin{array}{l}\text { People at risk of poverty or social } \\
\text { exclusion }\end{array}$ & -2638791.019 & 0.106 \\
\hline $\begin{array}{l}\text { Employment in knowledge- } \\
\text { intensive activities }\end{array}$ & -531484.454 & 0.488 \\
\hline $\begin{array}{l}\text { Harmonized index of consumer } \\
\text { price }\end{array}$ & 1491557.384 & 0.036 \\
\hline Tax rate on low wage earners & 5204173.051 & 0.021 \\
\hline $\begin{array}{l}\text { Labour productivity per person } \\
\text { employed and hour worked }\end{array}$ & 249012.048 & 0.659 \\
\hline Adult participation in learning & -7714790.847 & 0.031 \\
\hline $\begin{array}{l}\text { Impact of social transfers } \\
\text { (excluding pensions) on poverty } \\
\text { reduction }\end{array}$ & 265094.240 & 0.636 \\
\hline
\end{tabular}

Source: own calculations

According to the ridge generalized regression model, the number of unemployed immigrants from Italy depends on:

- $\quad$ Exports of goods and services (positive correlation; an increase in exports, which is a sign of growth of economic activity, implied less jobs for immigrants. This result might indicate that immigrants are less engaged in activities related to exports, which is confirmed by expectations. The Italian immigrants are concentrated in sectors with heavy physical work). This result was previously obtained by Dogan (2012) for Turkey. 
- Housing cost overburden rate (positive correlation; an increase in housing cost overburden rate put more pressure on immigrants, some of them being forced to give up to actual job with low salary in order to get a better paid job);

- People at risk of poverty or social exclusion (negative correlation; more poor or social excluded people are, less unemployed immigrants are, which means that poor immigrants made efforts to get faster a job);

- Harmonized index of consumer price (positive correlation; higher prices affected the salary of immigrants and some of them lost their job). This positive correlation obtained previously by Friedman (1977) indicates a big concern for policymakers that should implement measures to grow employment.

- Tax rate on low wage earners (positive relationship; higher tax on low wage earners motivates immigrants to search for a better paid job and give up to actual one). Koskela and Schöb (2007) indicated that government should tax mobile capital when high unemployment is present.

- Adult participation in learning (negative connection; more adults engaged in learning imply less unemployed immigrants, which means that the new knowledge help immigrants to get a job). The success of adult participation in learning was confirmed in Italy, while in other cases like in Belgium, this participation in learning did not increase employment for lowskilled young adults.

A significant correlation between GDP and number of unemployed immigrants was not observed which means that changes in the economic growth did not influence the status of immigrants on Italian labour market.

Beside these microeconomic and macroeconomic approaches for explaining the unemployment among Italian immigrants, we propose a new approach based on panel data that combines microeconomic data (unemployed immigrants/employed immigrants), macroeconomic data (GDP, total unemployment rate) with big data associated to different searches for jobs on Google. The number of unemployed immigrants and the number of employed immigrants will be explained based on macroeconomic indicators (GDP in PPS and national unemployment rate) and query indexes for subito it lavoro and offerte di lavoro as key-words to reflect searches for a job. These key-words were selected after the introduction of more key-words in Google Trends and for these words data were available by regions in the period 2008-2018. Subito it lavoro suggests a portal for free announcements including jobs offers. Offerte di lavoro reflects job opportunities. In this case, we have annual data for the 20 regions of Italy (Abruzzo ,Apulia, Basilicata, Calabria, Campania, EmiliaRomagna, Friuli-Venezia Giulia, Lazio, Liguria, Lombardia, Marche, Molise, Piemont, Sardinia, Sicilia, Toscana, Trentino, Umbria, Valle d' Aosta, Veneto).

The index provided by Google Trends indicates the queries volume of users that introduced into Google search those keywords, these users having a specific localization (regions of Italy, in this case). The query index is obtained by dividing the total query volume for a specific searched keyword in a region and the total number of queries in the same region and in the same period. Normalizations to 0 and 100 were made for these indexes (Simionescu \& Zimmermann, 2017). According to Askitas and Zimmermann (2009), the use of Google Trends brings some benefits, but limits could not be neglected. The main advantage is related to the possibility to define more relevant variables and construct the content using the definition and the words merge. The use of this tool depends on Internet penetration in that zone and these big data provides only an overall image of the individual behaviours of users.

Before the estimation of panel data models, we checked for data stationary. According to Levin-Lin-Chu test, all the data are stationary in level, excepting GDP that is stationary in first difference.

\begin{tabular}{lcc} 
Table 5: Levin, Lin \& & \multicolumn{1}{c}{ Chu test to check for stationary in panel } \\
\hline \multicolumn{1}{c}{ Variable } & Levin, Lin and Chu statistic & p-value \\
\hline Subito it lavoro & -9.55333 & 0.000 \\
Offerte di lavoro & -26.4833 & 0.000 \\
Unemployment rate & -5.51124 & 0.000 \\
Employed immigrants & -2985.57 & 0.000 \\
Unemployed immigrants & -45.0754 & 0.000 \\
GDP in PPS & -1.24458 & 0.1066 \\
GDP in first difference & -12.5953 & 0.0000 \\
\hline
\end{tabular}

Source: own calculations 
A fixed-effects model was built to explain the number of unemployed immigrants in the Italian regions during 2008-2018. We considered a level of significance of $10 \%$, the results of estimation being presented in Table 6.

The heteroscedasticity is examined using likelihood ratio tests applied for each regression model, while the presence of autocorrelation is examined using Wooldridge test for autocorrelation. The likelihood ratio tests confirm for all regressions the existence of homoscedasticity, while the Wooldridge statistics show the lack of autocorrelation.

Table 6: Fixed-effects model to explain the number of unemployed immigrants in the Italian regions (2008-2018)

\begin{tabular}{|c|c|c|c|c|}
\hline Variable & Coefficient & Std. Error & t-Statistic & Prob. \\
\hline$\overline{\mathrm{C}}$ & -17774.65 & 117014.5 & -0.151901 & 0.8795 \\
\hline offerte di lavoro & 3174.624 & 1763.757 & 1.799921 & 0.0739 \\
\hline GDP in first difference & -38.09063 & 11.48472 & -3.316637 & 0.0011 \\
\hline Subito it lavoro & 3691.234 & 1859.772 & 1.984778 & 0.0490 \\
\hline \multicolumn{5}{|l|}{ Fixed Effects (Cross) } \\
\hline _1-Constant & -153474.8 & & & \\
\hline 2 -Constant & 163407.5 & & & \\
\hline -3-Constant & -239438.0 & & & \\
\hline -4-Constant & -32011.62 & & & \\
\hline _5-Constant & 374860.2 & & & \\
\hline _6-Constant & 46167.01 & & & \\
\hline -7-Constant & -188282.3 & & & \\
\hline -8-Constant & 251860.5 & & & \\
\hline -9-Constant & -72711.21 & & & \\
\hline $10-$ Constant & 422126.1 & & & \\
\hline $11-$ Constant & -159453.1 & & & \\
\hline _12-Constant & -269634.7 & & & \\
\hline _13-Constant & 98119.97 & & & \\
\hline _14-Constant & -178995.3 & & & \\
\hline _15-Constant & 208191.6 & & & \\
\hline -16-Constant & 45098.66 & & & \\
\hline 11-Constant & -80734.32 & & & \\
\hline 18-Constant & -153297.2 & & & \\
\hline _19-Constant & -227709.1 & & & \\
\hline _20-Constant & 23785.66 & & & \\
\hline
\end{tabular}

Source: own calculations

The results indicated that the searches for jobs explain the actual number of unemployed immigrants in the Italian regions. These searches are positively correlated to unemployment while the variation in GDP has a negative impact on number of unemployed immigrants. These results are consistent with the economic theory: the panel data approach confirms the negative correlation between GDP and unemployment. The correlation between GDP and unemployment in Italy was previously studied by Piazza and Myant (2016) who showed indirect correlations between these indicators, but in the context of significant gaps between regions. Big data based on Google searches were previously used to explain unemployment rate at national level by Francesco (2009), D'Amuri and Marcucci (2010) and Falorsi et al. (2017) that used offerte di lavoro as key-word. Unlike these studies that consider the unemployment rate for all the residents in Italy (Francesco, 2009) or the Italian youth (Falorsi et al., 2017; Naccarato et al., 2018), our study is the first that explains only the unemployment among immigrants. Falorosi et al. (2017) used also subito.it lavoro as key-words, but with a different spelling compared to this study and only to predict youth unemployment. All the previous studies concluded that searches on Google using these key-words explain the unemployment rate in Italy, the correlation being a positive one like in this research. We can state that this hypothesis is also checked for Italian immigrants.

Another fixed-effects model was built to explain the number of employed immigrants in the Italian regions during 2008-2018 based on big data. A level of significance of $10 \%$ was used, the results of estimation being presented in Table 7. 
Table 7: Fixed-effects model to explain the number of employed immigrants in the Italian regions (2008-2018)

\begin{tabular}{lcccc}
\hline \multicolumn{1}{c}{ Variable } & Coefficient & Std. Error & t-Statistic & Prob. \\
\hline C & 810924.7 & 1127398 & 0.719289 & 0.4731 \\
D(GDP?) & -407.9256 & 110.6787 & -3.685675 & 0.0003 \\
Offerte di lavoro & 31203.31 & 16969.39 & 1.838800 & 0.0679
\end{tabular}

Fixed Effects (Cross)

1-Constant

2-Constant

$-1727885$.

3-Constant

$-592515.0$

4-Constant

-5-Constant

$-2525048$

$-1352341$.

702051.2

-6-Constant

1760786.

7-Constant

$-1122365$

-8-Constant

2202738.

9-Constant

$-183369.6$

10-Constant

7214996.

_11-Constant

-1334680 .

-12-Constant

$-2405481$

13-Constant

1170469.

_14-Constant

$-1103523$

15-Constant

$-405221.3$

-16-Constant

765677.7

_17-Constant

$-629298.1$

18-Constant

$-1650876$

19-Constant

$-2258428$

20-Constant

2470568.

Source: own calculations

The number of employed immigrants is explained by the variation in GDP and by the searches on Internet for the key-word offerte di lavoro. Higher the increases in GDP are, lower the number of employed immigrants are. This result might be explained by the fact that economic growth could generate more jobs for natives rather for immigrants. On the other hand, more searches for jobs on Google determined a growth in the number of employed immigrants. This result indicates that searches on the Internet using offerte di lavoro as key-word helped immigrants to find a job and integrate on labour market.

\section{Conclusions}

Migration in Italy is affected by supply pressure of the destination and origin countries. Initial migration resumed to low-skilled and low-paid jobs in construction, industry and agriculture. Later, the migration in Italy focused on family care sector, the old and sick people being supervised by foreign women. Moreover, housekeeping work in Italy is also made by immigrants. This substitution made by foreign people in family services sector allow skilled Italian women to integrate better on labour market.

Our research focused on more sources of data. According to survey data analysis based on representative samples of immigrants for Italian population, the foreign women have more chances than men to be employed on Italian labour market. In this case, females need less time to find a job compared to foreign men. Immigrants with higher education have less chances to get employed in their field compared to less educated immigrants. However, they adapt to the conditions in Italy. Therefore, the higher educated people prefer to wait less till they find a job since they have more skills that could allow them to make more types of unqualified jobs. Only in 2010, older people present more risks to not find a job. Romanian immigrants, the most numerous immigrants in Italy, have higher chances to get employed compared to immigrants from other origin countries, because most of them are interconnected in social networks that help them to find easier a job.

According to macroeconomic data used in constructing Bayesian generalized ridge regression, the number of unemployed immigrants from Italy since 2008 is explained by changes in: exports of goods and services, housing cost overburden rate, risk of poverty or social exclusion, inflation and tax rate on low wage earners and adult participation in learning.

The panel data approach based on microeconomic data, macroeconomic data and big data confirms that immigrants unemployment is also explained by Internet searches of migrants for jobs like in the case of overall Italian population as previous studies analysed.

The analysis is limited to a short number of years because we focused only on the period after the recent economic crisis start. However, the status of Italian immigrants in other periods of 
economic decline might be studied in a future research in order to make comparisons between different periods of economic recession with respect to situation of immigrants in Italy.

\section{Funding}

This research is part of the research plan of the Institute for Economic Forecasting of the Romanian Academy for 2021 with the title: The status of the Romanian migrants on the labour market of other EU countries.

\section{Conflicts of Interest}

The author declares no conflict of interest.

\section{Citation information}

Simionescu, M. (2021). The status of immigrants on Italian labour market in the context of economic decline: Evidence from survey, macroeconomic and big data. Economics, Management and Sustainability, 6(1), 34-48. doi:10.14254/jems.2021.6-1.3.

\section{Reference}

Ambrosini, M. (2013). Immigration in Italy: Between economic acceptance and political rejection. Journal of international migration and integration, 14(1), 175-194. https://doi.org/10.1007/s12134-011-0231-3

Albu, L. L., Iorgulescu, R., \& Stanica, C. (2010). Estimating hidden economy and hidden migration: The case of Romania. Romanian Journal of Economic Forecasting, 2(13), 46-56.

Arango, J., Bonifazi, C., Finotelli, C., Peixoto, J., Sabino, C., Strozza, S., \& Triandafyllidou, A. (2009). The making of an immigration model: Inflows, impacts and policies in Southern Europe. IDEA working papers, 9.

Askitas, N., \& Zimmermann, K. F. (2009). Google econometrics and unemployment forecasting (No. 4201). IZA Discussion Papers.

Awad, I. (2009). The global economic crisis and migrant workers: Impact and response (No. 433612). International Labour Organization.

Barnichon, R. (2010). Productivity and unemployment over the business cycle. Journal of Monetary Economics, 57(8), 1013-1025.

Bartolucci, F., Choudhry, M. T., Marelli, E., \& Signorelli, M. (2018). GDP dynamics and unemployment changes in developed and developing countries. Applied Economics, 50(31), 3338-3356.

Bonifazi, C., \& Paparusso, A. (2019). Remain or return home: The migration intentions of firstgeneration migrants in Italy. Population, Space and Place, 25(2), e2174.

Carlo, D. A., Lucifora, C., \& Pagani, L. (2012). A" Glass-Ceiling" Effect for Immigrants in the Italian Labour Market? (No. 6555). Institute for the Study of Labor (IZA).

Carvalho, J. (2013). Impact of extreme right parties on immigration policy: Comparing Britain, France and Italy (Vol. 20). Routledge.

Cohen, E. (2017). Effect of welfare and employment policies on the correlation between migration and unemployment. Economics \& Sociology, 10(1), 246.

D’Amuri, F., \& Marcucci, J. (2010). “Google it!” Forecasting the US Unemployment Rate with a Google Job Search index (No. 2010.31). Fondazione Eni Enrico Mattei.

D’Amuri, F., \& Marcucci, J. (2010). 'Google it!'Forecasting the US unemployment rate with a Google job search index.

de Ruggiero, A. (2018). A saudade dos sabores e o comércio étnico dos imigrantes italianos no Brasil (1875-1914). Revista Prâksis, 1, 121-138. 
Del Boca, D., \& Venturini, A. (2016). Migration in Italy is backing the old age welfare. In Labor migration, EU enlargement, and the great recession (pp. 59-83). Springer, Berlin, Heidelberg.

Del Boca, D., \& Venturini, A. (2016). Migration in Italy is backing the old age welfare. In Labor Migration, EU Enlargement, and the Great Recession (pp. 59-83). Springer Berlin Heidelberg.

Doğan, T. T. (2012). Macroeconomic variables and unemployment: the case of Turkey. International Journal of Economics and Financial Issues, 2(1), 71-78.

Doğan, T. T. (2012). Macroeconomic variables and unemployment: the case of Turkey. International Journal of Economics and Financial Issues, 2(1), 71-78.

Falorsi, S., Fasulo, A., Naccarato, A., \& Pratesi, M. (2017). Small area model for Italian regional monthly estimates of young unemployed using Google trends data. In Presented at the 61st World Statistics Congress ISI2017, 16-21 July 2017, Marrakech, Morocco.

Fellini, I. (2018). Immigrants' labour market outcomes in Italy and Spain: Has the Southern European model disrupted during the crisis?. Migration Studies, 6(1), 53-78.

Fleischmann, F., \& Dronkers, J. (2010). Unemployment among immigrants in European labour markets: an analysis of origin and destination effects. Work, employment and society, 24(2), 337-354

Francesco, D. A. (2009). Predicting unemployment in short samples with internet job search query data.

Friedman, M. (1977). Nobel lecture: inflation and unemployment. Journal of political economy, 85(3), 451-472.

Gavosto, A., Venturini, A., \& Villosio, C. (1999). Do immigrants compete with natives?. Labour, 13(3), 603-621.

Hatton, T. J., \& Williamson, J. G. (2009). Emigration in the long run: evidence from two global centuries. Asian-Pacific Economic Literature, 23(2), 17-28.

Heath, A., \& Yu, S. (2005). Explaining ethnic minority disadvantage. Understanding social change, 187224.

Hinks, T., \& Davies, S. (2015). Intentions to return: evidence from Romanian migrants. World Bank Policy Research Working Paper, (7166).

Hollifield, J., Martin, P., \& Orrenius, P. (2014). Controlling immigration: A global perspective. Stanford Univer.

Kahanec, M., Zaiceva, A., \& Zimmermann, K. F. (2009). Lessons from migration after EU enlargement. In EU labor markets after post-enlargement migration (pp. 3-45). Springer Berlin Heidelberg.

Karabatsos, G. (2014). Fast marginal likelihood estimation of the Ridge parameter (s) in Ridge regression and generalized ridge regression for Big Data. arXiv preprint arXiv:1409.2437.

Knipprath, H., \& De Rick, K. (2014). The economic benefits of adult learning to low-qualified young adults: Do participation and qualification decrease the risk of unemployment?. Vocations and Learning, 7(1), 101-120.

Koskela, E., \& Schöb, R. (2002). Why governments should tax mobile capital in the presence of unemployment. Contributions in Economic Analysis \& Policy, 1(1).

Koskela, E., \& Schöb, R. (2007). Tax progression under collective wage bargaining and individual effort determination (No. 2024). CESifo Working Paper.

Mara, I. (2012). Surveying Romanian migrants in Italy before and after the EU Accession: migration plans, labour market features and social inclusion (No. 378). wiiw Research Report.

Minneci, F. (2015). If there were a 'Highly Skilled Red Octopus'? The Case of Italian Highly Skilled Mobility at Times of Crisis. Economics and Sociology, 8(3), 170-182.

Naccarato, A., Falorsi, S., Loriga, S., \& Pierini, A. (2018). Combining official and Google Trends data to forecast the Italian youth unemployment rate. Technological Forecasting and Social Change, $130,114-122$.

Otobe, N. (2017). Gender dimensions of employment trends and future of work where would women work next? (No. 994971393102676). International Labour Organization. 
Papademetriou, D. G., Sumption, M., Terrazas, A., Burkert, C., Loyal, S., \& Ferrero-Turrión, R. (2010). Migration and immigrants two years after the financial collapse: Where do we stand. Washington, DC: Migration Policy Institute.

Piazza, G., \& Myant, M. (2016). Italy's labour market reforms of 2012: Did they reduce unemployment?.

Pont, B. (2004). Improving access to and participation in adult learning in OECD countries. European journal of education, 39(1), 31-45.

Reyneri, E. (2006). De la economía sumergida a la devaluación profesional: nivel educativo e inserción en el mercado de trabajo de los inmigrantes en Italia. Revista Española de Investigaciones Sociológicas (REIS), 116(1), 213-237.

Reyneri, E., \& Fullin, G. (2011). Labour market penalties of new immigrants in new and old receiving West European countries. International Migration, 49(1), 31-57.

Rugiero, S., Travaglini, G., \& Federici, A. (2018). The construction industry in Italy: crisis and opportunities over the last decade. Argomenti, 10(10), 1-33.

Saunders, P., Wong, M., \& Bradbury, B. (2016). Poverty in Australia since the financial crisis: the role of housing costs, income growth and unemployment. Journal of Poverty and Social Justice, 24(2), 97-112.

Schmiz, A. (2013). Migrant self-employment between precariousness and self-exploitation. Ephemera: Theory \& Politics in Organization, 13(1).

Schreiner, J. (2008). Labor Markets in Central, Eastern and Southeastern European EU Member States: General trends and Migration effects. Focus on European economic integration, 1(08).

Simionescu, M. (2014). Testing the Existence and Stability of Phillips Curve in Romania. Montenegrin Journal of Economics, 10(1), 67.

Simionescu, M. (2017). Macroeconomic determinants of migration from Romania to Italy. Computational Methods in Social Sciences, 5(1), 5-10.

Simionescu, M., \& Zimmermann, K. F. (2017). Big Data and Unemployment Analysis (No. 81). Global Labor Organization (GLO).

Stan, R. (2005). Patterns and Socio-Economic consequences of International labour migration on Catholic and Orthodox villages from Eastern Romania (Neamt county). A Tarkaság Dicsérete. Az Erasmus Kollégium Diákjainak Tanulmányai. Budapest: Erasmus Kollégium Alapítvány, 379393.

Subramaniam, T. (2008). The dynamic interactions among foreign direct investment, unemployment, economic growth and exports: Evidence from Malaysia. JATI-JOURNAL OF SOUTHEAST ASIAN STUDIES, 13, 35-48.

Tilly, C. (2011). The impact of the economic crisis on international migration: a review. Work, employment and society, 25(4), 675-692.

Trenz, H. J., \& Triandafyllidou, A. (2017). Complex and dynamic integration processes in Europe: intra EU mobility and international migration in times of recession. Journal of Ethnic and Migration Studies, 43(4), 546-559.

Uccellini, C. M. (2010). Outsiders after accession: The case of Romanian migrants in Italy, 1989-2009. Political perspectives, 4(2), 70-85.

Venturini, A., \& Villosio, C. (2006). Labour market effects of immigration into Italy: An empirical analysis 1. International Labour Review, 145(1-2), 91-118.

Venturini, A., \& Villosio, C. (2008). Labour-market assimilation of foreign workers in Italy. Oxford Review of Economic Policy, 24(3), 517-541.

Venturini, A., \& Villosio, C. (2018). Are migrants an asset in recession? Insights from Italy. Journal of ethnic and migration studies, 44(14), 2340-2357.

Vlase, I. (2013). 'My husband is a patriot!': gender and Romanian family return migration from Italy. Journal of Ethnic and Migration Studies, 39(5), 741-758. 
Zaiceva, A., \& Zimmermann, K. F. (2016). Returning home at times of trouble? Return migration of EU enlargement migrants during the crisis. In Labor Migration, EU Enlargement, and the Great Recession (pp. 397-418). Springer Berlin Heidelberg.

Zanfrini, L. (2015). The diversity value. How to reinvent the European approach to immigration.

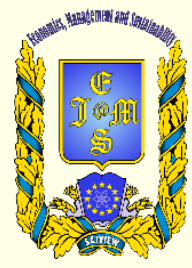

(c) 2016-2021, Economics, Management and Sustainability. All rights reserved.

This open access article is distributed under a Creative Commons Attribution (CC-BY) 4.0 license.

You are free to:

Share - copy and redistribute the material in any medium or format Adapt - remix, transform, and build upon the material for any purpose, even commercially.

The licensor cannot revoke these freedoms as long as you follow the license terms.

Under the following terms:

Attribution - You must give appropriate credit, provide a link to the license, and indicate if changes were made.

You may do so in any reasonable manner, but not in any way that suggests the licensor endorses you or your use.

No additional restrictions

You may not apply legal terms or technological measures that legally restrict others from doing anything the license permits.

Economics, Management and Sustainability (ISSN: 2520-6303) is published by Scientific Publishing House "CSR", Poland, EU and Scientific Publishing House "SciView", Poland

Publishing with JEMS ensures:

- Immediate, universal access to your article on publication

- High visibility and discoverability via the JEMS website

- Rapid publication

- Guaranteed legacy preservation of your article

- Discounts and waivers for authors in developing regions

Submit your manuscript to a JEMS at http://jems.sciview.net or submit.jems@sciview.net

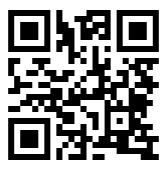

